\title{
THE AdMinistration OF JUSTICE? Certificate Proceedings, CHARKaOUi II, AND THE VALUE OF DisClOSURE
}

\author{
GRAHAM HUDSON*
}

\section{INTRODUCTION}

In the wake of 9/11, Canada was among a number of Western states that instituted a wide range of legal frameworks designed to more efficiently prevent and suppress transnational terrorism. ${ }^{1}$ One of the defining features of its national security policy has since been the integration of a selection of intelligence agencies into a global counterterrorism network. ${ }^{2}$ Operationally distinct agencies, such as the RCMP, the Canadian Security Intelligence Service (CSIS), the Communications Security Establishment, and the Canada Border Services Agency have been centrally coordinated towards the end of facilitating intelligence exchange within and across our borders. ${ }^{3}$ With few opportunities for public scrutiny or parliamentary and judicial review, ${ }^{4}$ the flow of information has gone on largely unregulated and, in a selection of notable cases, has contributed to serious human rights abuses both at home and abroad. ${ }^{5}$

Although a feature of Canadian law since 1976, security certificates are a conspicuous example of the human rights implications of unregulated global intelligence agency cooperation. Jointly issued by the Minister of Public Safety and the Minister of Citizenship and Immigration Canada (the Ministers), security certificates permit the Canadian government to detain and deport non-citizens who are alleged to be, inter alia, threats to Canadian national security. Certificate proceedings are formally features of immigration law and, by virtue of being administrative, have often been regarded as justifiably lacking in such values as full disclosure and adversarial challenge. Yet, they are also analogous to criminal law proceedings; the choice to name particular persons in security certificates is often based on intelligence derived from intrusive investigative techniques or from foreign, typically law-

* $\quad$ Assistant Professor, Department of Criminal Justice and Criminology, Ryerson University; Ph.D. Candidate, Osgoode Hall Law School, York University. Professor Hudson's research interests include security studies, legal theory, and human rights.

1 Some of the most conspicuous legislative changes were made in the context of criminal law through the Anti-terrorism Act, S.C. 2001, c. 41. However, national security policy has since been pursued more frequently through the Immigration and Refugee Protection Act, S.C. 2001, c. 27 [IRPA], which was initiated several months prior to 9/11.

2 Privy Council Office, Securing an Open Society: Canada's National Security Policy (Ottawa: Privy Council Office, 2004).

3 The coordination of these agencies is largely directed by the Integrated Threat Assessment Centre, online: Integrated Threat Assessment Centre <http://www.itac-ciem.gc.ca/index-eng.asp>.

$4 \quad$ See Kent Roach, "Must We Trade Rights for Security? The Choice Between Smart, Harsh, or Proportionate Security Strategies in Canada and Britain” (2006) 27 Cardozo L. Rev. 2151; Kent Roach, “The Three Year Review of Canada's Anti-terrorism Act: The Need for Greater Restraint and Fairness, Non-Discrimination, and Special Advocates” (2005) 54 U.N.B.L.J. 308.

5 Commission of Inquiry into the Actions of Canadian Officials in Relation to Maher Arar, Report of the Events Relating to Maher Arar: Analysis and Recommendations (Ottawa: Public Works and Government Services Canada, 2006) [Report of the Events Relating to Maher Arar]. See also International Commission of Jurists, Assessing Damage, Urging Action: Report of the Eminent Jurists Panel on Terrorism, Counter-terrorism and Human Rights (Geneva: International Commission of Jurists, 2009) at $67-90$. 
enforcement agencies, while the information tends to be used in an effort to return noncitizens to face arrests, detentions, and prosecutions abroad. ${ }^{6}$

In Charkaoui II, ${ }^{7}$ the Supreme Court of Canada had occasion to consider the constitutional dimensions of intelligence acquisition and distribution in the context of certificate proceedings. The case was concerned with the duties of CSIS, and the government in general, to retain and disclose information in their possession relevant to a person named in a security certificate. Following the principles it laid down in Charkaoui $I^{8}$ decided just a year earlier, the Supreme Court ruled that certificate proceedings are analogous to criminal proceedings, and that principles germane to the latter are applicable to the former. Relying on a range of criminal case law on the question of disclosure, the Court ruled that CSIS, although a civilian intelligence agency, is obligated to retain and disclose to reviewing judges and court-appointed special advocates all information on file that is relevant to a named person.

Charkaoui II reflects the Supreme Court's recent attempts to magnetize globalized Canadian national security law and policy around core constitutional values, ${ }^{9}$ and Federal Courts are following its lead. On 14 October 2009, a Federal Court judge quashed the certificate issued against Adil Charkaoui after the government withdrew key pieces of evidence in a bid to preserve its confidentiality. ${ }^{10}$ Relying on Charkaoui II, Tremblay-Lamer $\mathrm{J}$. ruled that the absence of evidence sufficient to support the reasonableness of a certificate rendered it illegal, and so ordered Charkaoui's unconditional release.

The purpose of this case comment is to reflect upon the significance of Charkaoui II in the full light of subsequent jurisprudence at the Federal Court level, up to and including Charkaoui's unconditional release. I will argue that the infusion of criminal law principles governing disclosure into certificate proceedings has improved the capacity of the courts to more proportionately balance national security and individual rights. I will also argue, however, that the overarching structure of certificate proceedings and the infusion by lower courts of exceptions to the duty to disclose suggest that changes to certificate-based detention and deportation practices are likely to be modest.

The comment will begin with a brief introduction to certificate provisions. It will progress to a review of the facts, issues, and significance of the case as well as of the decisions of the lower courts and of the Supreme Court. It will then move to an assessment of the extent to which the Supreme Court's decision has harmonized formal principles relating to disclosure in the context of certificate, criminal, and extradition proceedings. Finally, it will conclude the fact that there was a warrant issued for his arrest and legitimate concerns about the fairness of the Moroccan criminal justice system and the use of torture by Moroccan authorities to extract national security intelligence.

Charkaoui v. Canada (Citizenship and Immigration), 2008 SCC 38, [2008] 2 S.C.R. 326 [Charkaoui II].

8 Charkaoui v. Canada (Citizenship and Immigration), 2007 SCC 9, [2007] 1 S.C.R. 350 [Charkaoui I].

9 Ibid. at paras. 15-19; Canada (Justice) v. Khadr, 2008 SCC 28, [2008] 2 S.C.R. 125 at paras. 28-31 [Khadr]; Suresh v. Canada (Minister of Citizenship and Immigration), 2002 SCC 1, [2002] 1 S.C.R. 3 at paras. 3-4, 46, 106 [Suresh]. 
with an evaluation of how Federal Court judges have applied these principles in the context of post-Charkaoui II certificate proceedings.

\section{LEgISLATIVE CONTEXT: SECURITY CERTIFICATES}

Security certificates are issued under the joint powers of the Minister of Citizenship and Immigration and the Minister of Public Safety, ${ }^{11}$ and are issued against persons the Ministers allege are inadmissible to Canada on the grounds of security, the violation of human or international rights, and engagement in serious criminality or organized crime. ${ }^{12}$ Once issued, certificates authorize the detention of non-citizens pending a review of the reasonableness of the certificate by a Federal Court judge. Judges are required to order the continuation of a detention unless they are satisfied that the conditional release of a detainee would not be injurious to national security or endanger the safety of any person, or that the detainee would be unlikely to fail to appear at a proceeding or for removal. ${ }^{13}$

If a certificate is ultimately found to be reasonable, it stands as conclusive proof that the person named in it is inadmissible to Canada and becomes an effective removal order. ${ }^{14}$ However, during the course of reviews on the reasonableness of certificates, a named person may apply to the Minister of Citizenship and Immigration for protection as a refugee or person in need of protection. ${ }^{15}$ In the event that the application is successful the Ministers may still issue a danger opinion, ${ }^{16}$ enabling them to deport persons to face the substantial risk of persecution (which is consistent with international law) ${ }^{17}$ and, in exceptional circumstances, torture and similar abuses (which is inconsistent with international law). ${ }^{18}$

Certificate proceedings were designed to be administrative in nature. Even though those activities the engagement of which may trigger the issuance of a security certificate are often also elements of a number of criminal offences, named persons are denied many procedural protections associated with criminal proceedings. For instance, IRPA requires judges to conduct certificate and detention review proceedings "as informally and expeditiously as the circumstances and considerations of fairness and natural justice permit" and to receive into evidence anything that, in their opinion, "is reliable and appropriate even if it is inadmissible in a court of law, and may base their decisions on that evidence." 19 At the request of the Ministers, judges are required to hear evidence in the absence of the public, a person named in a certificate, and his counsel, if she is satisfied that the disclosure of such evidence "could be injurious to national security or endanger the safety of any person."20 She must also

The Minister of Public Safety (formerly the Minister of Public Safety and Emergency Preparedness) replaced the Solicitor General in this capacity in 2005: see IRPA, supra note 1, s. 4, as am. by S.C. 2005, c. 38 , s. 118 ; S.C. 2008 , c. 3, s. 1.

IRPA, ibid., s. 77(1).

Ibid., s. 82(5)(a).

Ibid., s. 80.

Ibid., s. $112(1)$

Ibid., ss. 115(2)(b), (3).

Convention relating to the Status of Refugees, 28 July 1951, 189 U.N.T.S. 150 (entered into force 22 April 1954, accession by Canada 2 September 1969), arts. 1(F), 33.

Convention Against Torture and Other Cruel, Inhuman or Degrading Treatment or Punishment, 10 December 1984, 1465 U.N.T.S. 85, arts. 2- 3, 16; Conclusions and Recommendations of the Committee against Torture: Canada, U.N.C.A.T., 34th Sess., UN Doc. CAT/C/CR/34/CAN (2005); Suresh, supra note 9 at paras. 59-75.

19 IRPA, supra note 1 , ss. 83(1)(a), (h).

20 Ibid., s. 83(1)(c) [emphasis added] 
maintain the confidentiality of that evidence for so long as its disclosure would be so injurious. ${ }^{21}$ While judges are required to provide named persons with a summary of the evidence that she has heard in private, ${ }^{22}$ IRPA authorizes decisions to be made on the basis of evidence not heard or responded to by named persons as well as evidence that has, for whatever reason, not been summarized and provided to named persons. ${ }^{23}$

Modest improvements were made to certificate provisions following the Supreme Court of Canada's 2007 ruling in Charkaoui I. After finding that certificate proceedings and criminal proceedings are analogous on the basis of the type and degree of their adverse impacts upon the life, liberty, and security of affected persons, the Court held that it was appropriate to import principles of fundamental justice developed in the context of the criminal law to certificate proceedings. ${ }^{24}$ In particular, it ruled that named persons are entitled to a fair hearing and that this includes the rights to know the case against them, to respond to that case, and to have decisions made on the basis of the facts and the law. ${ }^{25}$ It then ruled that excluding named persons and their legal counsel from significant portions of certificate proceedings is inconsistent with the right to a fair hearing and, consequently, s. 7 of the Canadian Charter of Rights and Freedoms. ${ }^{26}$

In an effort to comply with this decision the government has authorized security-cleared "special advocates" to represent named persons during secret proceedings, to access classified evidence, and to challenge that evidence as well as applications for nondisclosure. ${ }^{27}$ However, the value of disclosure is only partially realized as neither named persons nor their counsel are permitted, absent judicial authorization, to personally access confidential evidence or to converse with special advocates about any matter whatsoever once the latter has accessed such evidence. ${ }^{28} I R P A$ also does not expressly empower special advocates to subpoena documents or witnesses or, consequently, to demand disclosure of relevant information not submitted as evidence by the Ministers. Although flaws associated with these features of the special advocate system are well-documented, ${ }^{29}$ post-Charkaoui I certificate proceedings are nonetheless more reflective of criminal law values associated with disclosure, fairness, and adversarial challenge.

Ibid., s. 83(1)(d).

Ibid., s. 83(1)(e).

Ibid., ss. 83(1)(e), (i).

The principled basis for this application was established in Dehghani v. Canada (Minister of Employment and Immigration), [1993] 1 S.C.R. 1053 at 1077. For academic commentary on this point, see Hamish Stewart, “Is Indefinite Detention of Terrorist Suspects Really Constitutional?” (2005) 54 U.N.B.L.J. 235.

Charkaoui I, supra note 8 at para. 29.

Part I of the Constitution Act, 1982, being Schedule B to the Canada Act 1982 (U.K.), 1982, c. 11 [Charter].

IRPA, supra note 1, ss. 85.1(1)-(2), 85.2.

Ibid., ss. 85.4(2)-(3), 85.5.

For criticisms of the Canadian model, see Craig Forcese \& Lorne Waldman, Seeking Justice in an Unfair Process: Lessons from Canada, the United Kingdom, and New Zealand on the Use of "Special Advocates" in National Security Proceedings, online: University of Ottawa Faculty of Law <http:// aix1.uottawa.ca/ cforcese/other/sastudy.pdf $>$. For criticisms of the U.K. model, upon which the Canadian model was premised, see U.K., Joint Committee on Human Rights, "Review of Counterterrorism Powers, Eighteenth Report of Session 2003-2004,” HL Paper 158 in Sessional Papers, vol. 27 (2003-2004) at para. 40; U.K., H.C., Constitutional Affairs Committee, The operation of the Special Immigration Appeals Commission (SIAC) and the use of Special Advocates (London: The Stationery Office, 2005), online: Constitutional Affairs Committee <http://www.publications.parliament.uk/ $\mathrm{pa} / \mathrm{cm} 200405 / \mathrm{cmselect} / \mathrm{cmconst} / \mathrm{cm}$ const.htm>. 


\section{CHARKAOUi II: THE CASE}

\section{A. FACTS}

Charkaoui, a Canadian permanent resident, was named in a security certificate jointly issued on 9 May 2003 by the Minister of Citizenship and Immigration and the Solicitor General. A warrant for his arrest was issued on 16 May and executed on 21 May, at which point he was detained until his conditional release was ordered in February 2005. During that period, Charkaoui initiated a number of motions concerning the constitutionality of security certificate proceedings, the disclosure of evidence, and the procurement of his conditional release. For purposes of clarity, none of the proceedings hereinafter described were affected by the Charkaoui I decision as they, in most instances, preceded both this judgment and the subsequent amendments to IRPA. Further, while Charkaoui II was decided by the Supreme Court (but not by lower courts) subsequent to its ruling in Charkaoui I, the legal issues in the former were decided with no express reference to the changes in law initiated by the latter, simply because the issues on appeal arose in the context of the old provisions.

The first proceeding concerning Charkaoui occurred on 23 May 2003, at which time Noël J. of the Federal Court conducted an initial review of the reasons for Charkaoui's arrest and continued detention. ${ }^{30}$ On 30 May, Charkaoui was provided with an opportunity to respond to the case against him. On the advice of his counsel, Charkaoui requested that proceedings be postponed and, in July, he unsuccessfully applied to the Minister of Citizenship and Immigration for protection as a refugee or person in need of protection, pursuant to provisions governing pre-removal risk assessments. ${ }^{31}$ At the time, applications for protection had the effect of suspending the review of the reasonableness of the certificate. ${ }^{32}$ Charkaoui's application for protection was refused on 6 August 2004 and, on 9 November 2004, Noël J. scheduled the resumption of the review of the reasonableness of the certificate for 21 February 2005. However, upon hearing that Moroccan authorities had recently issued a warrant for Charkaoui's arrest, Noël J. ordered that the Minister of Citizenship and Immigration reconsider Charkaoui's request for protection. While this had the effect of suspending the resumption of the review of the reasonableness of the certificate scheduled for February, Noël J. properly proceeded to schedule a fourth detention review hearing for 10 January 2005.

Problems began on 30 December 2004 when the Ministers requested an ex parte, in camera hearing. The hearing was held on 5 January 2005, a mere five days before the commencement of Charkaoui's fourth detention review. During this hearing, the Ministers disclosed a summary of two interviews that were held between Charkaoui and CSIS on 31 January and 2 February 2002, and that had only recently come into their possession. Although CSIS had this summary in its possession in 2002, it failed to provide it to the Minister of Citizenship and Immigration and the Solicitor General both prior to their decision to issue the security certificate and immediately after the commencement of proceedings.

Re Charkaoui, 2005 FC 149, 261 F.T.R. 1 [Charkaoui].

IRPA, supra note 1 , ss. 112-16.

Ibid., s. 8, as am. by An Act to amend the Immigration and Refugee Protection Act (certificate and special advocate), S.C. 2008, c. 3, s. 4. 
Upon receiving the summary, Noël J. ordered that it be immediately provided to Charkaoui and the government complied.

The Ministers also submitted additional evidence during the 5 January hearing. This evidence, much of which was received from the Moroccan government, purportedly demonstrated that: Moroccan authorities had identified Charkaoui as a member of the Groupe Islamique Combattant Marocain (GICM); that the GICM is linked to al-Qaeda, and is allegedly responsible for terrorist attacks in Casablanca and Madrid, on 16 May 2003 and 11 March 2004, respectively; that Charkaoui took educational and theological training in Afghanistan in 1998; that Charkaoui was identified by the Emir of the GICM; that Charkaoui set up funds to support international terrorist cells; and that Charkaoui sent funds and resources directly to the GICM. Justice Noël provided Charkaoui with a summary of this new evidence on 6 January 2005. On 10 January, Charkaoui accepted Noël J.’s offer to adjourn and then postpone his fourth detention review so that he could review the summary of the interviews as well as the new evidence.

\section{B. LEGAL ISSUES}

In light of these facts, counsel for Charkaoui filed a request that the certificate be quashed and that Charkaoui be granted unconditional release. It was argued that Charkaoui was adversely affected by the delayed disclosure of the summary of the interviews, by the fact that CSIS had destroyed the original notes and recordings of these interviews, and by CSIS' failure to include facts favourable to Charkaoui in the summary. As a result of these facts, the security certificate was issued on the basis of incomplete information and, it was argued, its reasonableness could not be adequately tested. Counsel for Charkaoui further argued that CSIS is obligated to retain information pertaining to a person subject to an investigation and to disclose all such information, whether exculpatory or inculpatory, in a timely fashion. They argued that the failure of CSIS to discharge these obligations constituted a breach of procedural fairness as defined within s. 7 of the Charter.

Counsel for the Ministers responded by arguing that the Ministers' failure to disclose the summary of the interviews was unintentional and that they had taken the appropriate steps to remedy the problem by providing Charkaoui with both a summary of the interviews and an explanation for their omission. They further argued that this omission did not adversely affect Charkaoui because the summary constituted a small fraction of the total evidence against him, and because his testimony about the interviews would, if given, provide a more complete account of the interviews than would the summary. Finally, they argued that the destruction of original notes and recordings of interviews is consistent with CSIS policy as defined in relation to s. 12 of the Canadian Security Intelligence Service Act. ${ }^{33}$ Counsel for the Ministers maintained that original notes and recordings are no longer strictly necessary once summaries are compiled. 


\section{NORMATIVE ISSUES}

This case raises a number of important normative issues. One set of issues touch upon the norms that should govern CSIS' intelligence activities in the transnational context of Canadian national security. Traditionally, courts have been reluctant to hold CSIS to standards developed within the context of criminal law investigations. ${ }^{34}$ For instance, whereas law-enforcement agencies are required under s. 8 of the Charter to establish the “credibly-based probability" 35 of criminal conduct in order to justify intrusions of privacy, CSIS must merely show reasonable suspicion that an individual or group is engaged in activities which pose a threat to Canadian national security..$^{36}$ As mentioned, there are very few occasions in which courts have adapted the law to reflect Canada's participation in the free international exchange of national security intelligence, especially in relation to foreign law-enforcement functions. ${ }^{37}$ In like fashion, CSIS, along with other governmental institutions, has enjoyed wide discretion to deny to the public or affected individuals personal information collected during the course of its national security investigations. ${ }^{38}$

To its credit, CSIS voluntarily internalized s. 8 Charter jurisprudence regulating criminal investigations ${ }^{39}$ in the 1980 s by requiring its officers to pass a set of internal reviews before applying to the Federal Court for a warrant permitting the use of intrusive investigative techniques. ${ }^{40}$ Yet these reviews only occur during the course of domestic intelligence activities; no similar reviews are required regarding the acquisition of intelligence received from foreign agencies. In Charkaoui's case, CSIS relied on information provided by lawenforcement agencies operating in a country known to have a poor human rights record, particularly in the context of national security. ${ }^{41}$ There is no evidence to suggest that CSIS made efforts to ensure that the investigative techniques used to generate that information consisted with international or Canadian law. ${ }^{42}$ Until our courts rule to the contrary, CSIS'

Atwal v. Canada (Solicitor General), [1988] 1 F.C. 107 (C.A.) [Atwal]; Corporation of the Canadian Civil Liberties Association v. Canada (A.G.) (1998), 40 O.R. (3d) 489 (C.A.), aff'g (1992), 8 O.R. (3d) 289 (Gen. Div.).

Atwal, ibid. at para. 34, citing Hunter v. Southam Inc., [1984] 2 S.C.R. 145 at 168.

CSIS Act, supra note 33, s. 12.

One recent exception, which I will discuss in more detail in Part VI, below, is Khadr, supra note 9. Sections 19 and 21 of the Privacy Act, R.S.C. 1985, c. P-21, mandate heads of governmental institutions to refuse to disclose personal information that is received in confidence from foreign nations and permit them to refuse to disclose information the disclosure of which would, in their estimation, be injurious to, inter alia, counterterrorist activities. The constitutionality of these provisions was upheld in Ruby $v$. Canada (Solicitor General), 2002 SCC 75, [2002] 4 S.C.R. 3. See e.g. R. v. Wilson, [1983] 2 S.C.R. 594; R. v. Duarte, [1990] 1 S.C.R. 30; R. v. Chesson, [1988] 2 S.C.R. 148.

$40 \quad$ CSIS Act, supra note 33, ss. 21-28.

41 A number of independent reports on Morocco issued in 2004 highlight the regular use of torture and similar abuse, deplorable prison conditions, indefinite detentions, targeting of Muslims and other racialized minorities, excessive and unregulated use of emergency legislation, the lack of adequate legal representation for persons charged with broadly defined terrorism-related offences, the lack of due process, and the lack of an independent judiciary: see Human Rights Watch, "Morocco: Human Rights at a Crossroads," online: Human Rights Watch <http://www.hrw.org/reports/2004/morocco1004/>; Human Rights Committee, Considerations of Reports Submitted by State Parties Under Article 40 of the Covenant, Concluding Observations of the Human Rights Committee, Morocco, UN HRCOR, 82d Sess., UN Doc. CCPR/CO/82/MAR (2004) at paras. 10, 14, 15-17, 19-21. For a more recent report, see Amnesty International, “Amnesty International Report 2009: Morocco/Western Sahara,” online: Amnesty International < http://report2009.amnesty.org/en/regions/middle-east-north-africa/morocco>. The dangers of this are in some respects mitigated by the inadmissibility into certificate proceedings of information believed on reasonable grounds to have been acquired through the use of torture or similar abuse: see IRPA, supra note 1, s. 83(1.1). However, intelligence received through less egregious but still unlawful techniques is still admissible at reviewing judges' discretion (s. 83(1)(h)). 
extensive reliance on foreign sources, and foreign law-enforcement agencies in particular, permit it to stretch its intelligence activities beyond the reach of appropriate constitutional norms.

By circulating intelligence in the context of decisions about security certificates, CSIS further plays a pivotal role in returning non-citizens to face criminal prosecutions and the serious risk of human rights abuses abroad. Despite the functional associations between certificate proceedings and criminal and extradition proceedings, courts had, prior to Charkaoui I, consistently refused to infuse into the former principles and values germane to the latter. In Chiarelli v. Canada (Minister of Employment and Immigration), ${ }^{43}$ the Supreme Court held that persons named in a security certificate are not entitled to receive details concerning the state's investigative techniques or its human intelligence sources, even if it is clear that they were being deported for engaging in criminal activity and that their return would expose them to the likelihood of criminal prosecutions. ${ }^{44}$ What is more, the provision of any hearing whatsoever was held to be a privilege offered at the discretion of Parliament and not a matter of right. ${ }^{45}$ In consideration of whether the discretionary extension of a hearing to affected persons expanded Parliament's otherwise narrow constitutional obligations, the Court concluded that the provision of summaries of evidence was sufficient to enable named persons "to know the substance of the allegations against him, and to be able to respond” and, as such, brought the proceedings into compliance with principles of fundamental justice. ${ }^{46}$

Charkaoui II gave Canadian courts the opportunity to adapt these two streams of jurisprudence - one pertaining to civilian intelligence activities and the other to certificate proceedings - to the changing, transnational context of Canadian national security law and policy. To be sure, the integration of Canadian national security law and policy into international frameworks is necessary to contend with the threats posed by transnational terrorism. ${ }^{47}$ However, it is a question of great constitutional importance whether the Canadian government can use civilian intelligence and foreign national security agencies, as well as immigration and refugee law provisions, in an attempt to perform law-enforcement functions in relative autonomy from appropriate criminal law principles.

[1992] 1 S.C.R. 711 [Chiarelli].

Ibid. at 746 .

Ibid. at 742 .

Ibid. at 746 .

One of the basic observations of the U.S. 9/11 Commission was that terrorist attacks of this nature are preventable, but that inefficiency, competition, and decentralization within and between intelligence and law-enforcement agencies inhibited the U.S. government's capacity to quickly respond to terrorist threats: U.S., National Commission on Terrorist Attacks, The 9/11 Commission Report: Final Report of the National Commission on Terrorist Attacks Upon the United States (New York: W.W. Norton, 2004); U.S., National Commission on Terrorist Attacks, Final Report on 9/11 Commission Recommendations (Washington, D.C.: The Commission, 2005) at 2-3, online: 9/11 Public Discourse Project <http://www.9-11pdp.org>. Similar observations were made in Bob Rae's report on the Air India bombing: Bob Rae, Lessons to be Learned: The report of the Honourable Bob Rae, Independent Advisor to the Minister of Public Safety and Emergency Preparedness, on outstanding questions with respect to the bombing of Air India Flight 182 (Ottawa: Air India Review Secretariat, 2005) at 16-17. 


\section{DECISIONS OF THE LOWER COURTS}

On 1 February 2005, Noël J. ruled that any slight infringement of procedural fairness caused by CSIS and the Ministers' failure to make full disclosure in a timely manner could be remedied in ways that fell short of a stay of proceedings. ${ }^{48}$ Relying on the formal classification of certificate proceedings as administrative in nature, he rejected the submission that CSIS is obligated to provide all information in its possession to the Ministers prior to the latter's decision about whether or not to issue a certificate. In his view, CSIS was merely obligated to provide the Ministers with information in its possession that is relevant to the purposes of a security certificate proceeding; what constitutes "relevance" was left ambiguous and was, presumably, thought to be a matter best left to the discretion of CSIS and the Ministers. ${ }^{49}$ Making use of parallel distinctions between criminal and civilian investigations, Noël J. further ruled that it was not necessary to even "discuss the role of CSIS in the investigation, other than to say that CSIS is not a police agency and that it is not its role to lay charges."50

Writing for the Federal Court of Appeal, Pelletier J.A. upheld Noël J.'s ruling, although he took care to clarify some points. First, he affirmed Noël J.'s ruling that standards of evidence germane to criminal law ought not to be imported by the judiciary into certificate proceedings, ${ }^{51}$ that late disclosure was effectively remedied by a temporary suspension of proceedings, ${ }^{52}$ and that the disclosure to Charkaoui of the summary (but not the original notes) of the interviews was consistent with procedural fairness. ${ }^{53}$ Second, Pelletier J.A. clarified CSIS' general duty to disclose, ruling that information collected during the course of an investigation should be retained for "practical" purposes connected to determining the veracity of summaries and/or testimony. ${ }^{54}$ However, Pelletier J.A. ruled that it was purely “speculative” whether the Ministers' decision to issue a certificate, as well as Noël J.'s decisions regarding the reliability of evidence, would have changed had they possessed these notes earlier. ${ }^{55}$ Without a proper factual matrix, he refused to find that CSIS' failure to retain and disclose the original copies of its interviews with Charkaoui ran afoul of s. 7 of the Charter.

\section{The Decision of THE Supreme Court OF CANAdA}

\section{A. THE DUTY OF CSIS TO RETAIN INFORMATION}

Writing for the Supreme Court, LeBel and Fish JJ. upheld Pelletier J.A.'s ruling that CSIS has a statutory duty to retain operational notes that it has acquired during the course of its investigations. However, they went considerably further in detailing the nature and scope of this duty by relating it to CSIS' general role in national security investigations of a criminal nature, as well as to its specific role in certificate proceedings. With respect to CSIS' role in

Charkaoui, supra note 30 at paras. 14-15.

Ibid. at para. 16 .

Ibid. at para. 17.

Re Charkaoui, 2006 FCA 206, 272 D.L.R. (4th) 175 at para. 14.

Ibid. at para. 19.

Ibid. at paras. 33-36.

Ibid. at para. 29.

Ibid. at para. 32 . 
criminal investigations, LeBel and Fish JJ. noted that CSIS was originally designed to be a civilian security agency that was to operate independently of the RCMP. ${ }^{56}$ Although CSIS did, for some time, operate according to design, it has increasingly been co-operating with the RCMP in the investigation of threats to national security. Recognizing that the "activities of the RCMP and those of CSIS have in some respects been converging," and given that the information which CSIS collects and distributes may be used in criminal proceedings, the Supreme Court found it necessary to "qualify the finding of the Federal Court that CSIS

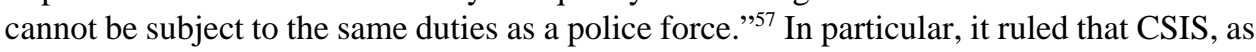
with police forces, ${ }^{58}$ is generally obligated to retain its operational notes.

Justices LeBel and Fish also noted that heightened duties of information retention are essential to improving the quality of ministerial decision-making prior to the commencement of certificate proceedings. Looking ahead to the issue of disclosure, they held that

[t]he submission of operational notes to the ministers and to the designated judge may be necessary to ensure
that a complete and objective version of the facts is available to those responsible for issuing and reviewing
the certificate. The retention and accessibility of this information is of particular importance where the person
named in the certificate and his or her counsel will often have access only to summaries or truncated versions
of the intelligence because of problems connected with the handling of information by intelligence agencies.
In addition, the destruction of information may sometimes hinder the ability of designated judges to
effectively perform the critical role, delegated to them by law, of assessing the reasonableness of security
certificates, reviewing applications for release by named persons and protecting their fundamental rights. ${ }^{59}$

The Court cited a decision by CSIS' reviewing body, the Security Intelligence Review Commission, that notes that CSIS' policy of destroying operational notes has been a source of "long-running concern" and that "[c]omplainants frequently allege that the investigator's report of their interview is not accurate: that their answers are incomplete, or have been distorted or taken out of context." 60 The Court also cited O'Connor J. who, in his report on Canada's role in exposing Maher Arar to grave human rights abuses abroad, stated that " $[\mathrm{t}] \mathrm{he}$ need for accuracy and precision when sharing information, particularly written information in terrorist investigations, cannot be overstated." 61

The Court moved to qualify CSIS' duty to retain its operational notes by stating that it must only retain notes collected during the course of investigations that target specific individuals or groups. It further held both that the retention of operational notes does not by itself guarantee procedural fairness, and that CSIS' failure to retain operational notes does not by itself mean that related investigations are unlawful. ${ }^{62}$ Rather, judges must make a caseby-case assessment of whether CSIS officers' breach of their general duty to retain

Charkaoui II, supra note 7 at paras. 21, 24. For the origins of this model, see Commission of Inquiry Concerning Certain Activities of the Royal Canadian Mounted Police, Freedom and Security under the law: Second Report, vol. 2 (Ottawa: Supply and Services Canada, 1981).

Charkaoui II, ibid. at paras. 26, 28.

R. v. La, [1997] 2 S.C.R. 680 [La].

Charkaoui II, supra note 7 at para. 42.

Ibid. at para. 40, citing Liddar v. Deputy Head of the Department of Foreign Affairs and International Trade and Canadian Security Intelligence Service, File No. 1170/LIDD/04 (7 June 2005) at para. 72. Charkaoui II, ibid. at para. 41, citing Report of the Events Relating to Maher Arar, supra note 5 at 114. Charkaoui II, ibid. at paras. 45-46. 
operational notes have led to the violation of, inter alia, named persons' right to procedural fairness.

\section{B. DISCLOSURE OF INFORMATION}

The Court began its discussion of CSIS' duty to disclose its operational notes by reviewing relevant criminal law jurisprudence. The standard rule in criminal law, laid down by the Supreme Court in $R$. v. Stinchcombe ${ }^{63}$ is that Crown attorneys are obligated to provide the defence all relevant information in their possession, irrespective of whether that information is inculpatory or exculpatory and of whether or not they intend to submit the information as evidence; as a corollary of this duty, police forces are generally obligated to retain their operational notes. ${ }^{64}$ In order to determine whether non-disclosure has breached the Charter, courts consider three factors: (1) whether there is a reasonable possibility that the undisclosed information was relevant; ${ }^{65}$ (2) whether non-disclosure of the information was justified for reasons of privilege (including police informant privilege) and, under some circumstances, the loss or destruction of relevant information; and (3) whether non-disclosure actually prejudiced an accused's capacity to make full answer and defence. ${ }^{66}$ Importantly, Stinchcombe does not guarantee full disclosure; the Crown may be exempt from the obligation to disclose for such reasons as privilege, the loss or destruction of relevant information, or the absence of adverse effects upon Charter rights.

Although courts hitherto had routinely found criminal law principles to be largely inapplicable to certificate proceedings, LeBel and Fish JJ. held that the force of Charter principles

does not turn on a formal distinction between the different areas of law. Rather, it depends on the severity of the consequences of the state's actions for the individual's fundamental interests of liberty and security and, in some cases, the right to life. ${ }^{67}$

Citing Charkaoui I, LeBel and Fish JJ. analogized certificate proceedings with criminal proceedings, holding that

[i]nvestigations by CSIS play a central role in the decision on the issuance of a security certificate and the consequent removal order. The consequences of security certificates are often more severe than those of many criminal charges. For instance, the possible repercussions of the process range from detention for an indeterminate period to removal from Canada, and sometimes to a risk of persecution, infringement of the right to integrity of the person, or even death.... Finally, it should be noted that the confirmation that a security certificate is reasonable is not a purely administrative measure, since a Federal Court judge must

[1991] 3 S.C.R. 326 [Stinchcombe].

La, supra note 58 .

In the case of information possessed by third parties, the standard has been raised to "likely to be relevant”: see R. v. O'Connor, [1995] 4 S.C.R. 411 [O'Connor].

There is some debate about whether this element should relate to the finding of a Charter breach or, alternatively, to the consideration of remedies. For a good view of this debate, see La, supra note 58; R. v. Egger, [1993] 2 S.C.R. 451; O’Connor, ibid.

Charkaoui II, supra note 7 at para. 53. 
make that determination. It is therefore simplistic to characterize the proceeding to determine whether a security certificate is reasonable as a purely administrative procedure. ${ }^{68}$

Justices LeBel and Fish ruled that the Crown's duty to disclose in the criminal law context is included within accused persons' right to make full answer and defence under s. 7 of the Charter and that, when applied to the context of certificate proceedings, it is included within named persons' s. 7 right to procedural fairness. ${ }^{69}$ This latter right was held to be an "expanded right," ${ }^{70}$ which includes a procedure for verifying the reliability and credibility of evidence as well as the disclosure of the evidence "in a manner and within limits that are consistent with legitimate public safety interests."

This last step in the Court's reasoning seems straightforward; the analogous nature of criminal and certificate proceedings warrant the application of Charter rights from one context to the other and, since the Crown's duty to disclose is part of accused persons' right to make full answer and defence, it follows that CSIS' duty to disclose is part of named persons' s. 7 rights. Further, since certificate proceedings are formally administrative in nature, the appropriate s. 7 right would seem to be the right to procedural fairness.

However, the Court did not clarify the scope of the duty of disclosure and, in particular, whether CSIS and the Ministers are obligated to disclose all relevant information in their possession, or whether they are obligated to disclose only that information which is necessary to test the veracity of submitted evidence. As mentioned earlier, Stinchcombe requires the Crown to disclose all relevant information in its possession, whether inculpatory or exculpatory, and whether or not it intends to submit this information as evidence. At first glance, it appears as though the Court in Charkaoui II intended disclosure to be similar in scope to that in Stinchcombe. In the opening paragraphs, the Court stated that CSIS "is bound to disclose to the ministers responsible all information in its possession regarding the person named in a security certificate. The ministers must convey this information to the designated judge."72

However, other aspects of the judgment suggest that the scope of disclosure will be narrower in the context of certificate proceedings than in criminal law proceedings. For instance, LeBel and Fish JJ. stated:

In our view, the issuance of a certificate and the consequences thereof, such as detention, demand great respect for the named person's right to procedural fairness. In this context, procedural fairness includes a procedure for verifying the evidence adduced against him or her. It also includes the disclosure of the evidence to the named person, in a manner and within limits that are consistent with legitimate public safety interests. $^{73}$

Ibid. at paras. 54-55.

Ibid. at para. 56.

Ibid. at para. 58.

Ibid. at para. 56.

Ibid. at para. 2.

Ibid. at para. 56. 
The Court continued by stating that, if "the original evidence was destroyed, the designated judge has access only to summaries prepared by the state, which means that it will be difficult, if not impossible, to verify the allegations." ${ }^{74}$ Read strictly, the Court seems to have ruled that the Ministers and CSIS are only obligated to adduce information that is necessary to test the veracity of evidence. If the government provides such information, the further disclosure of any additional information on file that might also be relevant to testing the veracity of evidence and which would be useful for supporting independent factual and legal arguments, would not be, strictly speaking, necessary. This interpretation would seriously restrict the scope and value of disclosure as it would give the government considerable discretion to selectively disclose information that, in all likelihood, would have comparatively limited exculpatory merit.

Read broadly, the Supreme Court's ruling is consistent with the proposition that all information on file pertaining to a named person is relevant to testing the veracity of any single piece of evidence. So, for example, while the original records of interviews may be the best means of testing the accuracy of a summary of interviews, employment records and other information pertaining to the credibility of interviewing officers, or documents that contain facts inconsistent with those contained in such a summary, may also be relevant. Of course, once the threshold of relevance is established, disclosed information may be used for a wide variety of purposes including the construction and support of independent legal and factual arguments; this is obviously why a low threshold of relevance would be preferable to named persons.

In any event, LeBel and Fish JJ. found that the operational notes were relevant and, for reasons already canvassed, that the destruction of the notes was unjustified. They did not, however, think it appropriate to grant a stay of proceedings. Rather, they remitted the issue to the Federal Court for consideration of whether CSIS' destruction of its operational notes had a "prejudicial effect" and if "Mr. Charkaoui should be granted a remedy."75 As regards the issue of delay in disclosure, the Court ruled that Noël J. had effectively remedied the problem by postponing proceedings to give Charkaoui time to review the new evidence. ${ }^{76}$

\section{What Makes Certificate Proceedings so Special?}

Government officials and judges have often invoked the exceptional and preventative nature of certificate provisions as justification for denying named persons a full range of procedural rights. Government officials assert that the nature of national security intelligence requires utmost secrecy and, consequently, the exclusion of named persons and their counsel from significant portions of proceedings; no further compromise between secrecy and procedural fairness is, in their estimation, possible. As has been seen, judges have generally deferred to these assertions. ${ }^{77}$ 
On closer inspection, the justifications offered for refusing to apply criminal law principles to certificate proceedings, and to CSIS during the course of its national security investigations, are unpersuasive. To begin with, certificate proceedings are exceptional by design, not by virtue of something so immutable as "nature," while nothing much hinges on their being preventative rather than punitive. Many of the activities the engagement of which justify the naming of a person in a security certificate are also offences under Part II.I of the Criminal Code.$^{78}$ Indeed, this Part of the Criminal Code, enacted through s. 4 of the Antiterrorism Act, expressly implements a number of international treaties and UN Security Council resolutions pertaining to the suppression and prevention of terrorist activity, the latter of which obligate member states to use criminal law provisions to punish transnational terrorist activity. ${ }^{79}$ In cases where Canada lacks the jurisdiction or means to prosecute persons for extra-territorial criminal activity there exists the option of extradition. Indeed, UN Security Council Resolution 1373 expressly obligates states to use both immigration and extradition law provisions to facilitate the return of suspected terrorists to face criminal prosecutions abroad. ${ }^{80}$ It is worthwhile to briefly explain how Charkaoui II-type disclosure affects the interrelationship among these three types of proceedings.

According to Canadian law, a person may be extradited if they have committed a specific offence within the jurisdiction ${ }^{81}$ of the country requesting extradition on the condition that there is an extradition agreement between Canada and that country, ${ }^{82}$ and that the relevant conduct would be a punishable offence if performed in Canada. ${ }^{83}$ The person whose extradition is sought generally appears at the extradition hearing and participates with the assistance of legal counsel. However, extradition hearings are not, under Canadian law, criminal trials. Affected persons do not enjoy the full protection of the Charter; ${ }^{84}$ judges must merely be satisfied that the evidence establishes a prima facie case that an extraditable crime has been committed in order to endorse an extradition request ${ }^{85}$ Further, judges' findings are merely advisory, as final decisions about extradition rest with the Minister of Justice.

Certificate proceedings are comparatively attractive for substantive, more so than procedural reasons. By virtue of judicial as well as statutory decree, Canada is precluded from extraditing persons to countries where they would face persecution or grave risks to their life, liberty, and security of the person. ${ }^{86}$ Prevailing norms suggest that extradition requests by countries without an independent judiciary or other core features of a fair criminal justice system ought to be refused. ${ }^{87}$ However, by virtue of art. 3(g) of UN Security

R.S.C. 1985, c. C-46, 2001; the Anti-terrorism Act, supra note 1, is no longer in force, but the amendments it made to the Criminal Code are.

For a small sample, see SC Res. 1373, UN SCOR, 2001, UN Doc. S/RES/1373 [Resolution 1373]; SC Res. 1540, UN SCOR, 2004, UN Doc. S/RES/1540; SC Res. 1624, UN SCOR, 2005, UN Doc. S/RES/1624.

Resolution 1373, ibid., arts. 2(e), 3(f).

There are five bases of jurisdiction in the field of international criminal law: territory, protection (of national interest), nationality of offender (active personality), nationality of victim (passive personality), and universality.

This "agreement” may take the form of a treaty, multilateral convention, or a discrete, person specific agreement.

Extradition Act, S.C. 1999, c. 18, s. 3(1).

United States v. Kwok, 2001 SCC 18, [2001] 1 S.C.R. 532.

United States v. Dynar, [1997] 2 S.C.R. 462 at para. 85.

Extradition Act, supra note 83, ss. 44(1)-(2); United States v. Burns, 2001 SCC 7, [2001] 1 S.C.R. 283;

Suresh, supra note 9.

Such is the case with Morocco: see supra note 41. 
Council Resolution 1373, politically motivated crimes - a category within which terrorist offences, as defined by the Canadian Criminal Code, fall ${ }^{88}$ — are not longer valid bases for refusing extradition requests.

A reasonable security certificate, by contrast, allows the deportation of an individual to face any potential human rights abuse save, under ordinary circumstances, torture. In the absence of disclosure the government can downplay the probability of abuses, claim remoteness as a factor absolving it of any actual abuses and, worse, use security certificates to remove individuals to countries for the purpose of facilitating intrusive investigations, arbitrary arrests and detentions, and unfair trials. Greater degrees of disclosure in certificate proceedings increase named persons' and special advocates' chances of identifying evidence of these motives. While this may not suffice to prevent findings of the reasonableness of a certificate or deportation, even small degrees of public disclosure can bring significant moral and international legal weight to bear upon the government.

Perhaps more significant are the ways in which Charkaoui II has helped harmonize the rules of disclosure applicable in certificate proceedings with those applicable in criminal proceedings. Generally, the non-disclosure of relevant information in criminal proceedings for reasons of international relations, national defence, or national security are governed by s. 38 of the Canada Evidence Act. ${ }^{89}$ Motions to prevent the disclosure of such information are initiated by the Attorney General and, for obvious reasons, are often conducted ex parte and in camera. ${ }^{90}$ Only during these proceedings may a judge hear, and decide upon, reliable and appropriate evidence that may ordinarily be inadmissible under Canadian law but that supports arguments for or against the non-disclosure of contested information. ${ }^{91}$ The admissibility of evidence heard ex parte and in camera, as well as any decision about it, are restricted to s. 38 motions; s. 38 is designed to prevent the disclosure of information that has not been submitted as evidence, in inter alia, criminal and extradition proceedings. Contested information is, for our purposes, merely information the government would be constitutionally obligated to disclose under Stinchcombe, but for s. 38 .

In order to balance secrecy and disclosure, s. 38.04(2)(c) allows an accused to apply to the Federal Court for an order requiring full or partial disclosure of information relevant to his defence. A judge must confirm the prohibition on the disclosure of even relevant information if he or she finds that disclosure would be injurious to international relations, national defence, or national security, and that the public's interest in non-disclosure is outweighed by its interest in disclosure. ${ }^{92}$ In such a case, however, judges are authorized to consider ordering partial disclosure. ${ }^{93}$ Consequently, if full disclosure is not possible, an accused may still receive redacted copies or summaries of relevant information. They might then have

Criminal Code, supra note 78, s. 83.01(1)(b), where terrorist activity is defined as, inter alia, acts or omissions committed "in whole or in part for a political, religious or ideological purpose."

R.S.C. 1985, c. C-5, as am. by R.S.C. 2001, c. 41 [CEA]. The constitutionality of this provision was upheld in Canada (A.G.) v. Khawaja, 2007 FCA 388, [2008] 4 F.C.R. 3, leave to appeal to S.C.C. refused, [2008] 1 S.C.R. ix.

CEA, ibid., s. 38.04(5).

Ibid., s. 38.06 (3.1).

Ibid., ss. 38.06(1)-(2).

Such a ruling was made in Khadr v. Canada (A.G.), 2008 FC 549, 329 F.T.R. 80. 
insight into where to independently search for additional information or what legal arguments might be best to use.

Section 38 decisions to prohibit the disclosure of relevant information can clearly affect the ability of an accused to make full answer and defence during criminal proceedings. In like fashion, common law bases for circumscribing the Crown's duty to disclose, such as those pertaining to confidential police sources, also may have negative effects upon an accused. Even in consideration of common law and statutory limits to the duty of disclosure, certificate proceedings are, from the government's standpoint, an attractive alternative to criminal and extradition proceedings. Again, this is because security certificate provisions always permit the government to submit as evidence information that is not disclosed to named persons; something that neither s. 38 nor common law exceptions to the duty to disclose permit in criminal proceedings. Accordingly, the government need never risk having to choose between disclosing sensitive information or abandoning proceedings, as it has in some criminal law cases touching on national security. ${ }^{94}$

It is true that Charkaoui I requires the government to disclose secret evidence to special advocates, but strict limitations on communication between special advocates and named persons seriously limit their ability to collaboratively interpret relevant information and select appropriate legal strategies. However, by requiring CSIS and the Ministers to disclose to the court all information on file relevant to a named person, the Supreme Court has supplemented post-Charkaoui I amendments to IRPA, remedying special advocates' inability to subpoena relevant documents and witnesses. This has introduced elements of compromise present in s. 38 of the CEA into certificate proceedings. Decisions about the relevance of information as well as about what information can safely be disclosed are no longer left to the discretion of CSIS and the Ministers. Reviewing judges, with the benefit of arguments from the Ministers and special advocates, are now authorized to consider what previously withheld information may be disclosed to named persons, their counsel, and the public. In cases where such information cannot safely be disclosed to named persons, judges are able to order partial disclosure in the form of summaries. Of course, it remains the case that named persons and their counsel may never see information submitted as evidence, which is never the case in the criminal context. Nonetheless, special advocates will always be able to access both secret evidence and confidential, relevant information on file in order to protect the interests of named persons in their absence.

Similar approaches to disclosure have recently been applied to certain classes of extraterritorial national security proceedings in which Canadian officials, including CSIS officers, have participated. In Khadr, decided just before Charkaoui II, the Supreme Court ordered the Minister of Justice, the Minister of Foreign Affairs, the Director of CSIS, and the Commissioner of the RCMP to disclose all records in their possession pertaining to interviews conducted by Canadian officials with Omar Khadr while held in Guantanamo Bay. It further ordered the government to disclose records of any "information given to U.S. authorities as a direct consequence of Canada’s having interviewed” Khadr. ${ }^{95}$

94 John D. McCamus, “Introduction” in Peter J. Hanks \& John D. McCamus, eds., National Security: Surveillance and Accountability in a Democratic Society (Cowansville, Que.: Editions Yvon Blais, 1989) at 9-10. 
In issuing this ruling, the Court rejected in part the government's argument that the Charter does not apply to Canadian officials while operating abroad and, therefore, that they are not required to comply with the values espoused in Stinchcombe. ${ }^{96}$ The Court responded by holding that, while international comity may ordinarily require Canadian courts to respect local law, this does not extend to laws that contravene Canada's international human rights obligations. Since the proceedings at Guantanamo Bay are inconsistent with international human rights, the Canadian government breached its international legal obligations by participating in them and could not avail itself of principles of international comity; ${ }^{97}$ there is no reason why this principle should not be applied to other extra-territorial proceedings such as those the initiation of which are made possible through certificate-based deportations. In any event, the Court remedied the Charter breach by requiring the government to disclose all material relevant to its participation in these proceedings. The Court was careful to specify that this obligation is not grounded in Stinchcombe and that only material relating to the interviews had to be disclosed; any other information pertaining to Khadr, even if relevant to the proceedings in Guantanamo Bay, did not have to be disclosed. ${ }^{98}$ It also ruled that the scope of disclosure is subject to s. 38 of the $C E A .^{99}$

\section{Post-Charkaoui II Certificate Proceedings}

As always, one of the most important questions to be asked is: will Charkaoui II be effective? While long-term projections are difficult, case law in the past year suggests that Charkaoui II has significantly improved Federal Courts' handling of issues of disclosure in certificate proceedings. Although subsequent case law is applicable to all persons named in certificates, proceedings concerning Mohamed Harkat have generally been the site where Charkaoui II has had the most visible effect. In the fall of 2008, the Federal Court required CSIS and the Ministers to "file all information and intelligence related to Mohamed Harkat including but not limited to drafts, diagrams, recordings and photographs in CSIS' possession or holdings.” ${ }^{100}$ These files included information well beyond that which had been initially provided to the Court as part of CSIS' Security Intelligence Report on Harkat and, consequently, that which supported the Ministers' allegations. The Federal Court in this respect interpreted the scope of Charkaoui II disclosure broadly and consistently with Stinchcombe, so as to include all relevant information in the government's possession, whether inculpatory or exculpatory, and whether or not the government intends to submit it as evidence.

There have since been a number of motions filed that have expanded and contracted the scope of disclosure, signifying a steep learning curve in just how closely certificate proceedings are to be modeled after criminal proceedings. Again in the case of Harkat, the government has disclosed 2,000 documents containing at least 8,000 pages to the Court and to Harkat's special advocate in order to comply with Charkaoui II. ${ }^{101}$ Initially, the Ministers had redacted significant portions of this information based on their considerations of

Ibid. at para. 17 .

Ibid. at paras. 25-26.

Ibid. at para. 37.

Ibid.

Re Harkat, 2009 FC 340, 33 F.T.R. 129 at para. 4 [Harkat].

Ibid. at para 7. 
relevance and privilege, “including covert human intelligence source privilege.”"102 On 12 March 2009, the Federal Court lifted most redactions made to 67 contested documents. ${ }^{103}$ On the opposite side of the spectrum, the Court later ruled that special advocates are only entitled to such information as is "necessary to examine and verify the accuracy of the information submitted" to the Court; ${ }^{104}$ setting the threshold of relevance to "necessary" raises the bar well beyond the "reasonable possibility" test stipulated in Stinchcombe, and is an area in which the government's duty to disclose may be sharply circumscribed in the future.

In a more recent hearing, the Federal Court denied special advocates' request for access to the employment records of a former CSIS officer who had earlier testified against Harkat. Relying on O'Connor, ${ }^{105}$ special advocates had argued that these records were likely to be relevant to the proceeding and, since they were obligated to maintain the confidentiality of any disclosed information, third parties in possession of this information had no reasonable expectation of privacy. ${ }^{106}$ The Ministers responded that, since criminal law principles are now applicable to certificate proceedings, related common law rules of privilege also apply. The Court agreed with the Ministers, holding that the employment records were not necessary to verify the accuracy of available evidence. ${ }^{107}$

In a similar motion, special advocates for Harkat sought an order compelling the Ministers to produce, for cross-examination, covert human intelligence sources who had provided information about Harkat to CSIS. ${ }^{108}$ They argued that cross-examination was necessary to test the credibility of the information and to corroborate elements of Harkat's testimony. Making use of the Supreme Court's ruling that criminal law principles are applicable to both certificate proceedings and civilian intelligence activities, the Ministers responded that police informer privilege, a recognized exemption from the duty to disclose in criminal proceedings, ${ }^{109}$ is applicable to certificate proceedings and to sources recruited by civilian intelligence agencies. The Federal Court recognized the merit of both sides, ruling that disclosure of a covert human intelligence source requires proof that disclosure is necessary to "prevent a flagrant denial of procedural fairness which would bring the administration of justice into disrepute." ${ }^{\text {"110 }}$ It further held that the fact that certificate proceedings are closed does not, by itself, override common law privilege or the policy on which it is based. ${ }^{111}$ This judgment highlights that criminal law principles can be effectively used to limit the government's obligation to disclose.

Most recently, disputes over the proper scope of the Ministers' Charkaoui II disclosure obligations led to the quashing of Charkaoui's security certificate on 14 October 2009. Subsequent to Charkaoui II, Charkaoui's counsel and special advocates requested the disclosure of high volumes of previously unreleased information. Notwithstanding the

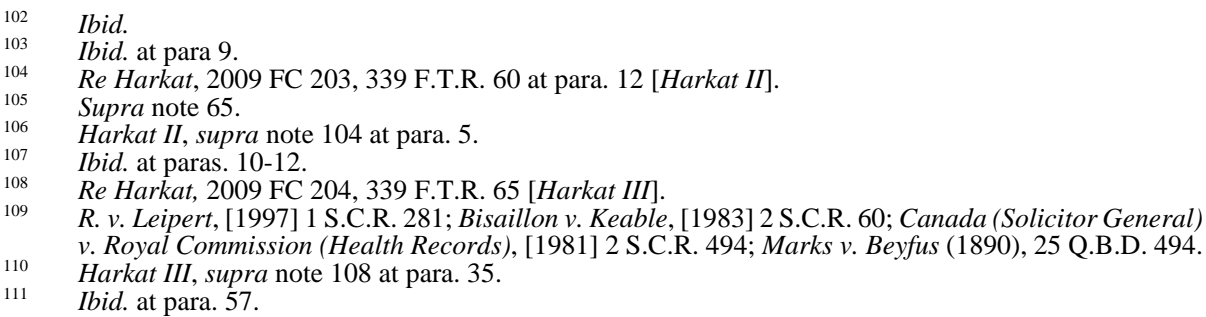


Ministers' arguments to the contrary, the reviewing judge, Tremblay-Lamer J. of the Federal Court, ruled that certain evidence could be disclosed to Charkaoui without compromising national security or the safety of any person. ${ }^{112}$ She proceeded to order the Ministers to disclose this evidence directly to Charkaoui and to further submit, during closed hearings, original copies of CSIS' operational notes pertaining to this evidence. Justice TremblayLamer then indicated that she would forward to Charkaoui summaries of these originals and associated information, and would include details the Minister had insisted could not be safely disclosed.

Disputing the factual question of whether or not this information could safely be disclosed, the Ministers invoked s. 83(1)(j) of IRPA, which reads: "the judge shall not base a decision on information or other evidence provided by the Minister, and shall return it to the Minister, if the judge determines that it is not relevant or if the Minister withdraws it.”113

By withdrawing key evidence, the Ministers deprived the Court of its authority to compel the disclosure of the contested information, either in full or in summary form. Of course, by withdrawing all of this information, the Ministers lacked evidence sufficient to support the reasonableness of Charkaoui's certificate; a fact that they expressly admitted. ${ }^{114}$

In the absence of supporting evidence, Tremblay-Lamer J. ruled that there were no statutory bases for the certificate; it was null, void, and ultra vires the authority of the Ministers. ${ }^{115}$ She based this judgment on s. 77(2) of IRPA, which requires the Ministers to "file with the Court the information and other evidence on which the certificate is based."116 The withdrawal of supporting evidence rendered impossible a review of the reasonableness of the certificate, and so it had, in Tremblay-Lamer J.'s estimation, to be quashed. Justice Tremblay-Lamer proceeded to deny the Ministers' request to have certified questions for the Federal Court of Appeal, holding that there were no questions of general importance raised in this case. ${ }^{117}$ She had, in her view, appropriately applied the criteria laid down in Charkaoui II, finding as a matter of fact that certain evidence could safely be disclosed to Charkaoui. The Ministers might have disagreed with this determination, but there was no legal basis for them to withdraw the contested evidence while maintaining the certificate against Charkaoui. It remains to be seen whether the Ministers will reissue a certificate against Charkaoui in the future, relying on evidence the disclosure of which they can live with.

\section{CONCLUSION}

In light of subsequent jurisprudence and Charkaoui's unconditional release, Charkaoui II has had an undeniably significant impact on certificate proceedings. Special advocates have received, and made effective use of, greater disclosure, while the applicability of criminal law principles to certificate proceedings has made available for use a range of exceptions to the government's duty to disclose. Although Charkaoui II has improved levels

Re Charkaoui, supra note 10 at paras. 85-93.

Supra note 1.

Re Charkaoui, supra note 10 at paras. 25, 85-90.

Ibid. at para. 24.

Supra note 1.

Re Charkaoui, supra note 10 at paras. 92-93. 
of disclosure, then, there remain a variety of wrinkles to be ironed out regarding the right balance to be struck between privilege and procedural fairness. One might also question the extent to which CSIS and the Ministers will comply with the ruling, considering that the existence of national security intelligence is, by its nature, known only to those who possess it. While there has been one documented instance in which CSIS has admitted to illegally withholding relevant information, the seriousness with which this omission was taken by the Federal Court and some officials suggest that the Ministers have generally complied with their obligations. ${ }^{118}$

Although successful in many ways, the impact of Charkaoui II on detention and deportation practices is likely to be limited by the continued operation of a deeply problematic administrative regime and an associated culture of secrecy. The reality is that named persons and their counsel are still denied access to all but summaries of information disclosed to special advocates; Federal Courts have adopted high standards concerning what constitutes relevant information; there are still powerful statutory prohibitions on unauthorized communications between special advocates and named persons (and their counsel); the Ministers still need only demonstrate that their allegations are reasonable to initiate deportation proceedings; and they may yet issue another certificate against Charkaoui. Still, the correlation between increases in the circulation of information and improvements in the quality of judgment is plausible, as is the ever-present possibility of, and urgent need to, more effectively balance national security and individual rights. For now, Charkaoui II stands, in no small measure, as evidence that these are goals that are still worth striving for. 